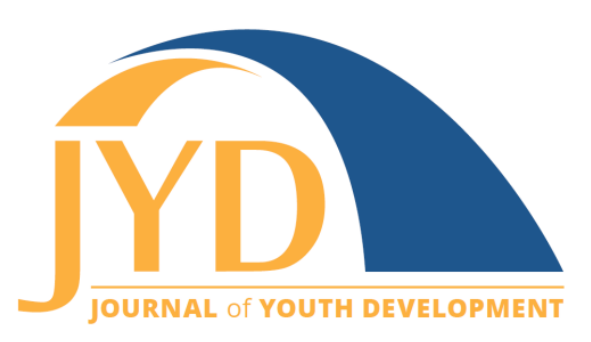

http://jyd.pitt.edu/ | Vol. 16 Issue 1 DOI 10.5195/jyd.2021.1093 | ISSN 2325-4017 (online)

\title{
Book Review-Measure, Use, Improve! Data Use in Out-of-School Time
}

\author{
M. Maureen Toomey \\ University of Idaho, 4-H Youth Development \\ mtoomey@uidaho.edu
}

\begin{abstract}
Measure, Use, Improve! Data Use in Out-of-School Time offers out-of-school time (OST) professionals practical lessons and approaches to measurement and data use. Editors Christina A. Russell and Corey Newhouse assembled notable contributors who offer conversant perspectives on evaluation systems within diverse OST organizations. Its 4 thematic sections address issues and provide action-oriented solutions from OST programs, evaluation intermediaries, and funders. Key discussions across chapters include (a) moving forward using data to inform continuous quality improvement, (b) supporting youth development professionals, (c) ensuring equity and inclusion in the evaluation process, and (d) recognizing what it takes to move forward.
\end{abstract}

Key words: out-of-school time, evaluation, continuous quality improvement, youth voice, staff development

Measure, Use, Improve! (Russell \& Newhouse, 2021) provides youth development professionals (YDP), administrators, evaluators, and researchers practical lessons and approaches to data measurement and use. It is organized into four thematic sections covering issues and actionoriented solutions from out-of-school time (OST) programs, evaluation intermediaries, and funders. The Introduction and the Epilogue define and conclude the key discussions across chapters: (a) moving forward using data to inform continuous quality improvement, (b) supporting youth development professionals, (c) ensuring equity and inclusion in the evaluation process, and (d) recognizing what it takes to move forward.

Part I: Setting the Stage: The Value of Measurement and Evaluation provides several steps for designing and planning for OST evaluation. Evaluation is a learning process with multiple steps

(cc) EY New articles in this journal are licensed under a Creative Commons Attribution 4.0 License. This journal is published by the University Library System, University of Pittsburgh and is cosponsored by the University of Pittsburgh Press. The Journal of Youth Development is the official peer-reviewed publication of the National Association of Extension 4-H Youth Development Professionals and the National AfterSchool Association. 
and requires various inputs. Recognizing that the word evaluation may invoke fear and anxiety, the authors suggest positive approaches to thinking, planning, and engaging in the process at the site, organizational, or network level. Table 1 outlines key content in each chapter.

Table 1: Key Content in the Value of Measurement

\begin{tabular}{|c|c|}
\hline Chapters & Key content \\
\hline \multicolumn{2}{|c|}{ Part I: Setting the Stage: The Value of Measurement and Evaluation } \\
\hline $\begin{array}{l}\text { 1. Taking Stock: Investing in Measuring } \\
\text { Our Work in Out-of-School Time, } \\
\text { Regino Chávez }\end{array}$ & $\begin{array}{l}\text { - An OST evaluator's personal view of how evaluation } \\
\text { serves multiple purposes with a focus on moving } \\
\text { from fear and anxiety to evaluation curiosity }\end{array}$ \\
\hline $\begin{array}{l}\text { 2. What's Your Why? Matching Evaluation } \\
\text { Approach to Organizational Need, } \\
\text { Jason Spector }\end{array}$ & $\begin{array}{l}\text { - Consideration of OST organizational capacity for an } \\
\text { outcome-based evaluation plan } \\
\text { - Exploration of a 5-year internal evaluation process } \\
\text { from After-School-All-Stars }\end{array}$ \\
\hline $\begin{array}{l}\text { 3. Using Data for Learning: A Funder's } \\
\text { Perspective, Rebecca M. Goldberg, } \\
\text { Ashleigh L. Halverstadt, and Alex C. } \\
\text { Hooker }\end{array}$ & $\begin{array}{l}\text { - Discussion of open and honest conversations among } \\
\text { stakeholders to realistically set evaluation priorities } \\
\text { - Insights from case studies for building trusting, } \\
\text { transparent relationships between OST and funders }\end{array}$ \\
\hline
\end{tabular}

The evaluation design involves defining youth and stakeholders' program outcomes, outlining specific achievable objectives, and considering barriers to achieving outcomes. Continuous quality improvement (CQI) regularly addresses practices and how they make, or do not make, the program better, with a focus on improving the lives of youth. Evaluation takes time, and the authors suggest that the plan be multi-year and inclusive of staff, administrators, and stakeholders to ease the evaluation process, making it routine, and creating an environment of evaluative curiosity.

Reconciling organizational needs with funders' expectations may initially appear challenging. However, funders and administrators are shifting their visions to support embedded evaluation for CQI. Trust between OST administrators and funders is key to advancing discussions on funding alignment, assessing internal capacity for multi-faceted evaluation planning, and being up-front about evaluation priorities. 
Part II: Building Blocks for Evaluation covers making data and tools meaningful to OST programs, selecting the right data system, being inclusive of cultural contexts and perspectives, allowing local ownership of data, and effectively employing youth participatory evaluation. YDP or practitioners (staff, managers, administrators) must be intentionally prepared to deliver highquality, equitable, and culturally relevant programs. Strategies and tools to make data meaningful are presented starting with a discussion on using a program logic model and theory of change. Coupling a well-crafted logic model with a theory of change may clarify the evaluation path. A look at data systems for small to middle-sized programs addresses the current system's ability versus what is needed and how uneven "tech-spertise" among staff plays into ongoing evaluation. Solutions and practical tips are offered such as stay mission focused, skip procrastination and shame zones, and allocate resources and staff to be effective. Table 2 outlines key content in each chapter.

Table 2. Key Content in Building Blocks for Evaluation

\section{Chapter}

Part II: Building Blocks for Evaluation

4. Demystifying Data: Strategies and Tools for Making Data More Meaningful in OST Programs, Hannah L. Lantos, Zakia Redd, Brandon Stratford, and Aasha Joshi

5. Navigating Data Systems Selection: Tools to Ease the Journey, Betsy Block

6. What, So What, Now What: A GameWinning Plan for Capacity Building, Tasha Johnson and Aasha Joshi

\section{Key content}

- Selection of correct tools and strategies for organizational implementation of meaningful and fruitful evaluation plan

- Two-part narrative covers (a) understanding data and what data to collect and (b) using a performance management cycle to promote effective use of data

- Data collection systems for small to mid-size programs

- Four challenges and solutions for using datainformed approaches including goal achievement, crafting a theory of change, and ongoing change

- YMCA's competency-based approach for capacity building

- Use of framework (What?, So What?, Now What?) supports positive program implementation, staff and volunteer allocation, and resource use 
Table 2. (continued)

\begin{tabular}{|c|c|}
\hline Chapter & Key content \\
\hline \multicolumn{2}{|l|}{ Part II: Building Blocks for Evaluation } \\
\hline $\begin{array}{l}\text { 7. From Quantity to Quality: Lessons } \\
\text { Learned From an Ongoing Statewide } \\
\text { Initiative, Kim Firth Leonard, Celeste } \\
\text { Janssen, and Belle Cantor }\end{array}$ & $\begin{array}{l}\text { - Oregon's K-12 Student Success: Out-of-School Time } \\
\text { Initiative for middle school youth strategy for } \\
\text { organizational learning and continuous quality } \\
\text { improvement } \\
\text { - Conversation on student success, learning across } \\
\text { the organization, and moving from quantity to } \\
\text { quality of programming from Oregon Community } \\
\text { Foundation and Institute for Youth Success at } \\
\text { Education Northwest }\end{array}$ \\
\hline $\begin{array}{l}\text { 8. Putting Data to Work for Young } \\
\text { People: Bridging Practice and Research } \\
\text { Through Continuous Improvement, } \\
\text { Jessica Donner, Anamarie Auger } \\
\text { Whitaker, Ann Durham, and Lisa Gomi } \\
\text { Hui }\end{array}$ & $\begin{array}{l}\text { - Every Hour Counts' efforts to measure local capacity } \\
\text { needs and ability to collect and analyze data to drive } \\
\text { improvement } \\
\text { - Securing stakeholders commitment to program } \\
\text { outcomes and building an environment of data- } \\
\text { driven program improvement }\end{array}$ \\
\hline $\begin{array}{l}\text { 9. Youth Participation in Evaluation: } \\
\text { Lessons From the Past, Opportunities } \\
\text { for the Future, Joseph Luesse and Kim } \\
\text { Sabo Flores }\end{array}$ & $\begin{array}{l}\text { Description and implementation strategies of Youth } \\
\text { Participatory Evaluation tool }\end{array}$ \\
\hline
\end{tabular}

The YMCA of the USA's Character Development Learning Institute (Chapter 6) builds practitioners' knowledge and application of positive youth development elements, thus ultimately enhancing the youth experience. Comparable organizations can adapt the Y's approach to professional development. In addition to well-trained YDP, OST can benefit from using practitioners as coaches. Keeping program quality as the central theme, a train-thetrainer model delivered by Oregon's intermediary trains YDP coaches to build local capacity. Through this model, trained YDP, evaluators, and funders are positioned to converse with stakeholders, accept feedback, and make changes.

The intermediary organization's role is to continuously improve the caliber of OST thus ensuring access for youth to high-quality programs, especially youth from limited-resourced families and communities. In Chapter 8, Every Hour Counts, a coalition of OST intermediary organizations, 
describes how its data measurement framework supports Boston After School \& Beyond and Providence After School Alliance in program self-assessment (Yoo et al., 2019). Every Hour Counts offers 10 recommendations for effective data selection, collection, and management.

Youth Participatory Evaluation (YPE) includes young people in evaluation practices of planning, data collection, analysis, and community reporting (Chapter 9). YPE helps young people build thinking, leadership, and communication skills while expanding their social capital. The process of using YPE to improve programs and direct positive community change are discussed including organizational buy-in, planning for YPE, recruiting and involving youth, and preparing staff to engage youth as colleagues.

Part III: Developing Systems of Evaluative Thinking examines the use of CQI by OST intermediaries to build YDP's evaluative thinking skills. Evaluative thinking and strategies are described, along with case studies from several intermediaries, followed by recommendations to implement data-informed CQI. Notably, intentionally gathering youth feedback is an effective aspect of CQI. Table 3 outlines key content in each chapter.

Table 3. Key Content in Developing Systems of Evaluative Thinking

\begin{tabular}{|l|l} 
Chapter & Key content
\end{tabular}

Part III: Developing Systems of Evaluative Thinking

10. Building Effective Continuous Quality Improvement Systems: The Need for Evaluative Thinking About Out-ofSchool Time Program Quality, Tiffany Berry and Michelle Sloper

11. Building Evaluative Thinking Skills and Capacity Through $\mathrm{M} 3{ }^{\circledR}$ (Making Mean with Multiple Data Sets), Jocelyn Wiedow and Jennifer Griffin-Wiesner

12. A Reservoir of Insight: Tapping Youth Feedback to Inform Continuous Learning, Valerie Threlfall
- Discussion of program quality as multi-faceted, multi-dimensional, highly variable, and challenging to achieve

- Strategies for building CQI through evaluative thinking

- Examples of OST intermediaries merging of data systems (YPQA, Cityspan, SAYO) to better understand and present program impacts

- Evaluative thinking skills and Making Meaning with Multiple Data Sets (M3®) process

- Rationale and best practices for collecting youth feedback for continuous improvement 
Table 3. (continued)

\begin{tabular}{|c|c|}
\hline Chapter & Key content \\
\hline \multicolumn{2}{|c|}{ Part III: Developing Systems of Evaluative Thinking } \\
\hline $\begin{array}{l}\text { 13. How a Frontier State Grew OST } \\
\text { Quality From the Ground Up, Linda } \\
\text { Barton, Kathy Schleyer, and Ellen } \\
\text { Gannett }\end{array}$ & $\begin{array}{l}\text { - Case study from Wyoming Afterschool Alliance on } \\
\text { establishing key partnerships and leveraging } \\
\text { resources } \\
\text { - Demonstration of a small organization's } \\
\text { accomplishment of system-wide quality } \\
\text { improvement goals }\end{array}$ \\
\hline $\begin{array}{l}\text { 14. Beyond Youth Outcomes: Thinking } \\
\text { Outside the Logic Model, Bryan Hall } \\
\text { and Brenda McLaughlin }\end{array}$ & $\begin{array}{l}\text { - Relationship between school (academic focus) and } \\
\text { out-of-school (enrichment focus) } \\
\text { - Case study from BellXcel Summer on program staff } \\
\text { experience learning alongside youth }\end{array}$ \\
\hline
\end{tabular}

Part IV: Using Data and Evaluation to Improve Staff Capacity addresses the professional development of and support needed for the YDP. One staff retention study strongly indicates YDP believe in their organizations and the positive impacts they have on the lives of youth (Angbah, 2018). Building staff capacity requires organizations regardless of size, to have an onboarding and retention plan embedded into the CQI scheme. CQI is greatly enhanced by YDP competencies that inform the hiring process, develop a scope and sequence for professional learning focused on skill building, and identify career trajectory for staff. Table 4 outlines key content in each chapter. 
Table 4 . Key Content in Using Data and Evaluation to Improve Staff Capacity

\begin{tabular}{|c|c|}
\hline Chapter & Key content \\
\hline \multicolumn{2}{|c|}{ Part IV: Using Data and Evaluation to Improve Staff Capacity } \\
\hline $\begin{array}{l}\text { 15. Giving Data a Voice Through } \\
\text { Coaching: The Michigan Example, } \\
\text { Jamie Wu, Trevor Davies, Lorraine } \\
\text { Thoreson and Laurie Van Egeren }\end{array}$ & $\begin{array}{l}\text { - Coupling evaluation and coaching to support data- } \\
\text { driven CQI } \\
\text { - Pooling expertise and resources YPQI, Weikart } \\
\text { Center of the Forum for Youth Investment; } 21^{\text {st }} \\
\text { CCLC; Michigan Department of Education; Michigan } \\
\text { After-School Partnership; Michigan State University; } \\
\text { Technical Assistance and Coaching Support System } \\
\text { - Discussion of lessons learned and recommendations } \\
\text { for building professional capacity }\end{array}$ \\
\hline $\begin{array}{l}\text { 16. Walk the Path Together: Partnering to } \\
\text { Advance Data Use, Miranda Yates, } \\
\text { Stephanie Mui, and Jennifer Nix }\end{array}$ & $\begin{array}{l}\text { - Creating a culture of learning through authentic and } \\
\text { productive partnerships between the evaluators and } \\
\text { the practitioners } \\
\text { - Moving from top-down driven evaluation plan to } \\
\text { shared and collaborative approach }\end{array}$ \\
\hline $\begin{array}{l}\text { 17. Using Data Informed Practices to } \\
\text { Support the Onboarding and Retention } \\
\text { of Youth Development Professionals, } \\
\text { Jaynemarie Enyonam Angbah }\end{array}$ & $\begin{array}{l}\text { OST staff retention through successful onboarding } \\
\text { and ongoing professional development for frontline } \\
\text { staff }\end{array}$ \\
\hline
\end{tabular}

Measure, Use, Improve! Data Use in Out-of-School Time brims with lessons, practices, processes, and recommended resources. It is an ideal tool for professional development training for after-school programs and youth-serving organizations. OST intermediaries and networks could employ Measure, Use, Improve! to guide a system-wide evaluation process. OST administrators could create study teams focusing on relevant chapters. Even well-established youth development organizations could use selected chapters to benchmark their CQI plans. The authors have provided a rich collection of references for further reading.

\section{References}

Angbah, J. (2018). Bringing youth development full circle: Exploring the factors that limit educational and work-based learning opportunities for youth development professionals. 
Journal of Youth Development ｜ http://jyd.pitt.edu/ | Vol. 16 Issue 1 DOI 10.5195/jyd.2021.1093 Book Review: Measure, Use, Improve!

https://s3.amazonaws.com/pase-conferences/2018-Conference/Jaynemarie-Angbah-BringingYouth-Development-Full-Circle.pdf

Russell, C. A., \& Newhouse, C. (Eds.). (2021). Measure, use, improve! Data use in out-of-school time. Information Age Publishing.

Yoo, P., Whitaker, A., \& McCombs, J. S. (2019). Putting data to work for young people: A ten-step guide for expanded learning intermediaries. RAND Corporation.

https://www.everyhourcounts.org/s/RAND-10-Steps.pdf 